\title{
POLITIKK
}

SKANDINAVISK TIDSSKRIFT

FOR INTERNASJONALE STUDIER

Årgang 80, Nummer 1, side 1-5, 2022, ISSN 1891-1757, www.tidsskriftet-ip.no, Publisert januar 2022

\section{Den militære profesjonen}

\author{
Harald Høiback \\ Forsvarets museer, Norge
}

Torunn Laugen Haaland, Rolf Hobson \& Kjell Inge Bjerga

Den militere profesjonen, staten og samfunnet - introduksjon til militere studier

Cappelen Damm Akademisk (2021)

Når veletablerte forskere som Torunn Laugen Haaland, Rolf Hobson og Kjell Inge Bjerga setter av tid til å skrive bok om den militære profesjonen, er det lov å ha høye forventinger. De tre beveger seg også gjennom et terreng hvor de er vel bevandret.

Boken består av tre deler, hvor den første har tittelen «Profesjon» og handler om hvorfor vi har et militært forsvar, og hvordan det styres og samvirker med samfunnet for øvrig. Del II, «Krig og samfunnsendring», er en tour de force hvor vi får et godt blikk inn i hvordan militærmakten og samfunnet det er en del av har utviklet seg i Europa fra opplysningstiden. I del III, «Sikkerhets- og forsvarspolitikk», ser vi på utviklingen av norsk sikkerhetspolitikk fra 1945 og fram til i dag.

Mye av det vi finner i boka, er forbilledlig klart skrevet. Best er boka der den ikke handler om den militære profesjonen, men om militær- og krigshistorie. Den militære profesjonen, derimot, spesielt den norske, er trioen bemerkelsesverdig lite interessert i.

\section{Det sivil-militære problemet}

Det største savnet i boka er at forfattertrioen ikke tar seg tid til å forklare målgruppen, som er førsteårs bachelorstudenter i Militere studier ved Forsvarets høgskole, hva det sivil-militære problemet egentlig grunner i. 


\section{Harald Høiback}

Kjernen i forholdet mellom den sivile og militære ledelsen, og som boka tangerer mange steder, men aldri tar seg tid til å forklare, er at militærmakt befinner seg både $i$ og utenfor politikken på en måte som ingen andre etater gjør.

I det daglige må offiserer finne seg $\mathrm{i}$ en politisk detaljstyring som ville vært utenkelig i en rettssal eller i Rikshospitalets operasjonsstuer. En jurist vil aldri akseptere at utfallet av en rettssak skal være fortsettelsen av den sittende regjeringens politikk med andre midler. En kirurg vil heller aldri akseptere at et partiprogram skal fortelle henne hvordan hun skal fjerne en betent blindtarm. En offiser, derimot, må pent akseptere at en flankemarsj må tilrettelegges for begge kjønn.

I ekstreme situasjoner derimot, er det demokratiet som hviler på Forsvarets skuldre, ikke motsatt. Det var det 9. april lærte oss. Om Forsvaret ikke virker den dagen det blir satt på prøve, finnes det ikke lenger noe demokrati. Det finnes heller ingen politisk styring eller faglig uavhengighet. Forsvaret skal virke også om Stortingets medlemmer er spredt for alle vinder, og statsministeren er tatt til fange og tvunget til å beordre opphør av striden. Hvor eksepsjonelt dette forholdet er, at Forsvaret både skal være tam som en skjødehund og giftig som en klapperslange, blir ikke forklart.

I trioens beskrivelse av de dramatiske hendelsene i Washington i januar 2021 går vi også glipp av viktige innsikter om det spesielle forholdet mellom politisk og militær ledelse. De gir USAs øverste militære ledere gode skussmål for at deres lojalitet lå hos de demokratiske institusjonene (s. 66). De sier imidlertid påfallende lite om forsvarssjef Mark A. Milleys handlinger på denne tiden. Vurderte han å nekte å utføre den lovlige valgte presidentens ordre? Og har en general egentlig lov til å nekte å starte tredje verdenskrig om det er det presidenten ber ham om å giøre, uansett grunn? Og hvor mye honnør bør egentlig den tyske hærledelsen få for at de på 1930-tallet valgte å følge en annen folkevalgt politiker, Adolf Hitler, ut i avgrunnen? Hadde det vært sterkt klanderverdig om de heller hadde skutt ham ved daggry? Er offiserenes lojalitetsplikt overfor de politiske myndigheter helt uten vilkår så lenge vedtakene er lovlig fattet? Dette er det sivil-militære problemet i et nøtteskall. En bok om den militære profesjonen, staten og samfunnet bør si noe fornuftig om slikt, spesielt om den er skrevet for profesjonen selv.

Der er også en gjenganger i boka at perioder med mistillit mellom den politiske og militære ledelsen forklares med at sistnevnte ikke forstår seg på politikk og demokratiets vesen. For eksempel finner vi: «Det er likevel ingen tvil om at det både før og nå fantes og finnes en skepsis til både politikere og Forsvarsdepartementet $\mathrm{i}$ den militære organisasjonen, og en oppfatning om at forsvaret av Norge er så viktig at det er 'hevet over politikken'. En slik innstilling er åpenbart problematisk.» (s. 43).

En slik innstilling er ikke problematisk, men kjernen i det sivil-militære problem. Andre etater kan selvfølgelig også komme under et sterkt press, men ingen andre etater har som Forsvaret som del av sin eksistensberettigelse at de med våpen $\mathrm{i}$ hånd skal virke også etter at den politiske ledelsen har sluttet å svare telefonen. På den måten er de hevet over politikken. I det daglige, derimot, styres som nevnt Forsvaret 
enda mer politisk enn det andre etater giør, og det er derfor ikke rart at mange som har sett hvordan det foregår på nært hold nærer en viss skepsis til prosessen.

Politikere lever av det antall stemmer de vinner ved valg, ikke av om vi får mest mulig forsvarsevne ut av de kronene som avsettes til forsvar. Forsvarssektoren er også spesielt utsatt for dyrt valgflesk fordi Forsvaret, i motsetning skole, helse og samferdsel, ikke trenger å virke hver eneste dag. Det blir langt flere ubehagelige overskrifter i VG om operasjonene på Haukeland går i stå, enn om de i Forsvarets fellesoperative hovedkvarter giør det.

Den normale responsen på min innvending om at ganske mange forsvarspolitiske beslutninger er suboptimale, er at dette er prisen vi må betale for et velfungerende demokrati. Det er jeg enig i. Valgte politikeres jobb er nettopp å veie ulike og ofte kryssende hensyn opp mot hverandre, og i det arbeidet har de også rett til å ta feil, ta snarveier og bruke skattepenger for å sikre gjenvalg. Slik må det være. Men forståelsen studentene får av de sivil-militære relasjoner blir ganske ensidig om man ikke tar departementalt markeringsbehov og den partipolitiske konkurransen $i$ et levende demokrati med i analysen.

\section{Den norske militære profesjonen}

Den militære profesjonen i Norge har utvilsomt vært gjennom en dramatisk utvikling de siste årene. På den ene siden er profesjonen i praksis avviklet. Om en profesjon hviler på utdanning på akademisk nivå, monopol på visse arbeidsoppgaver, høy grad av intern kontroll og et bestemt samfunnsansvar (s. 23), er Forsvaret knapt til å kjenne igjen i forhold til hvordan det var for en generasjon siden. Tre av fire profesjonspilarer er i ferd med å smuldre bort.

Vi er på vei mot et Forsvar hvor man knapt skal ha profesjonsutdanning, kun ett års påbygg på en vilkårlig sivil bachelorgrad. Monopolet undergraves av omfattende in- og outsourcing av tidligere militære jobber til sivile, og den tette departementsstyringen gjør at den militære profesjonens interne kontroll er illusorisk. Lite av dette er vår trio opptatt av å fortelle sine bachelorstudenter om.

Boka er i så henseende i seg selv et uttrykk for hvor dårlig det står til med den militære profesjonen i Norge for tiden. Som jeg snart kommer tilbake til, minner forfatterne meg om leger som utreder helsetilstanden til en pasient uten å snakke med pasienten overhode. Hva pasienten - den militære profesjonen - mener, er ikke relevant. Profesjonen er i ferd med å bli umyndiggjort, også på sin egen utdanningsinstitusjon og i sitt eget pensum.

På den annen side er den militære profesjonen i Norge påfallende sterk, både i nasjonal og internasjonal målestokk. I Norge kan man se oberstløytnant Tormod Heier stå i kongens klær på direktesendt TV og radbrekke sittende statsråd i en politisk duell. Hvilken annen etat i Norge ville tillatt noe slikt? Det er vanskelig å se for seg at en tjenestemann i Skattedirektoratet kunne ha stilt i Debatten på NRK for å idiotforklare skattepolitikken til sittende statsråd. 


\section{Harald Høiback}

Enda mer bemerkelsesverdig er dette $i$ et internasjonal lys. Det er utenkelig at noen oberstløytnant $i$ vår del av verden kunne ha gjort som Heier uten at talepunktene hadde vært nøye kontrollert og frisert på forhånd. Dette er så oppsiktsvekkende at Heier ble tildelt Norsk PENs Ossietzkypris for fremragende innsats for ytringsfriheten i 2017. Deler av juryens begrunnelse var at: "Tormod Heier er en motstrøm-stemme i et konsensuspreget akademisk miljø i Forsvaret.» Men han var ikke mer motstrøm enn at generalløytnant Robert Mood fikk Fritt Ords Pris året før «for å ha vist ytringsmot i kritiske debatter om Forsvarets rolle i samfunnet».

Man skulle tro at ovennevnte ting er viktig å kjenne til om du skal forstå den norske militære profesjonen, men trioen er ikke opptatt av noe av dette. Det er utenfor radaren. Og ser man på den sparsommelige litteraturlista i boka forstår man raskt hvorfor. Der finner vi lite annen norskspråklig litteratur enn den som er produsert på Institutt for forsvarsstudier (IFS). Ikke et komma av alt det som er skrevet og publisert de siste femten årene av medlemmer av den militære profesjonen på Stabsskolen og de tre krigsskolene er å finne på litteraturlista. ${ }^{1}$ Heller ikke Hans P. Hosar "Offiserane - Stat, stand, parti, profesjon» i Rune Slagstad og Jan Messel, Profesjonshistorie (Pax, 2014) er å finne på litteraturlista. Det er derfor ikke rart om deres bachelorstudenter ender med å tro at alt som er verdt å lese om den militære profesjonen i Norge, er skrevet av forskere på IFS. Merkeligere er det at våre tre forfattere også later til å tro det.

\section{Stol på meg}

Det mest forunderlige med denne boka, er imidlertid fraværet av et note- og referanseverk. Denne mangelen er dobbelt uheldig.

Av sine metodelærere får bachelorstudenter høre til det kjedsommelige at det eneste det ikke finnes tilgivelse for, er å giengi andres tanker og akademiske arbeid uten å oppgi kildene. I denne boka serveres vi direkte sitat (f.eks. s. 12, 43, 74), parafraser (s. 73 og 197) og sentrale begreper uten at trioen oppgir sine kilder. Er for eksempel begrepet «sikkerhetisert» (s. 187) noe trioen har funnet på selv? Hva skal studentene tenke om denne bokas mangelfulle noteapparat? At professorer ved IFS er fritatt fra normal akademisk folkeskikk?

For det andre er fraværet av kildehenvisninger uheldig fordi det svekker det boka sier den vil oppnå: «å utvikle det fremtidige offiserskorpsets evne til selvstendig og kritisk tenkning» (s. 19). Det giengis debatter om både dette og hint, men trioen finner ingen grunn til å fortelle leserne hvor de kan gå for å sette seg mer inn i de ulike debattene.

Vi får også vite en hel mengde om hva offiserer har tenkt og ment om diverse utviklingstrekk de siste tiårene, uten at det legges fram noen form for belegg som

\footnotetext{
${ }^{1}$ Se f.eks. Edström, H., Lunde, N. T. \& Matlary, J. H. (Red.), Krigerkultur $i$ en fredsnasjon. Abstrakt forlag (2009); T. Heier (Red.), Nytt landskap - nytt forsvar. Norsk militermakt 1990-2000. Abstrakt forlag (2011).
} 
støtter analysen. For eksempel leser vi: «skepsis mot akademia og teoretisk lærdom kan synes å være en del av den militære kulturen» (s. 51), "[Det var] innad i Forsvaret en sterk profesjonsbasert motstand mot endringer fra et nasjonalt til et mer internasjonalt fokus» (s. 190) og "Militærledelsen ønsket å oppretteholder en stor overkommando i troen på at dette ga bedre 'strategisk' ledelse av Forsvaret, men det var i realiteten også et stort behov for stillinger til senioroffiserer som var for gamle for operativ tjeneste, men som hadde noen år igjen før de kunne gå av med pensjon [...] Etter årevis med tjeneste ute i distriktene, var mange særlig fornøyd med å få noen rolige år i hovedstaten på slutten av karrieren» (s. 191). Gjennom slike stadige og udokumenterte drypp skapes det i boka et inntrykk av at offiserer ikke tenker spesielt mye, men når de gjør det tenker de likt: 1) Min forsvarsgren må få mer, 2) alt var bedre før, og 3) alt amerikansk er bra. Slike sjablongpregede og karikerte salongversjoner av den militære profesjonen passer imidlertid ikke så godt i en lærebok, uansett nivå.

Det som slår en i Forsvaret, er nettopp hvor uenig man kan være om mange ting. Også internt i bransjer og forsvarsgrener diskuteres det så flisene fyker. Slike debatter burde forfatterne av denne boka invitert leserne med inn i, ved å oppgi kilder og tips til steder å grave videre. Ved å trekke stigen opp etter seg og holde sine kilder skjult, svekker de unektelig verdien av denne boka som innføringsbok.

\section{Konklusjon}

I boka skriver de tre forfatterne: «Erfaring viser at det kan oppleves som ubehagelig og provoserende å få et kritisk blikk rettet mot seg» (s. 20). Det er jeg enig i. Men det verste er å bli oversett. Det nest verste er å bli kritisert for ting man ikke har sagt eller ment. Det nest beste er å bli kritisert for noe man faktisk mener, og det aller beste er å få skryt. Hvorvidt mitt kritiske blikk på boka blir oppfattet som provoserende av de tre forfatterne, er heller tvilsomt. Anmeldelsen er ikke skrevet på IFS, og blir derfor neppe lest i de kretser. Men om de skulle gjøre det, vil forfatterne oppdage at jeg i det minste har tatt dem på alvor.

Konklusjonen er at dette på mange måter er en velskrevet bok hvor vi får gjensyn med mange av trioens tidligere glansnumre, og som jeg tror vil tjene deler av sin hensikt godt. Det gode den har å bidra med, har riktignok vært sagt bedre andre steder, og da med referanser. Spesielt kan bokas del II leses som en ønskereprise med stort utbytte for folk i farta som uansett ikke har tid til eller interesse av å grave videre i Clausewitz' tanker, Polens deling eller industrialiseringen.

De to andre delene av boka bør derimot leses mer som en levning enn som en kilde. De sier langt mer om IFS som utkikkspunkt og det egosentriske tunnelsynet som for tiden råder der, enn om den militære profesjonen i Norge i dag. Det kan jeg gjerne siteres på. 